\title{
IDENTIFICAÇÃO DAS UNIDADES DE PAISAGEM EM TRECHO DO CENTRO DA CIDADE DE MACAÉ, RIO DE JANEIRO, BRASIL
}

\author{
IDENTIFICATION OF THE LANDSCAPE UNITS IN A CENTER STRETCH \\ OF THE CITY OF MACAÉ, RIO DE JANEIRO, BRAZIL
}

\author{
Fernanda de Abreu Pereira \\ Danielly Cozer Aliprandi
}

RESUMO
A cidade de Macaé, localizada no interior do estado do Rio de Janeiro,
conhecida como a capital nacional do petróleo, recebeu este título por
ser um polo importante para a gestão da atividade petrolífera brasileira.
As interferências dessa atividade atingiram diversos aspectos da cidade,
como a economia, o crescimento populacional, a expansão urbana e,
consequentemente, a paisagem. Com o interesse em caracterizar a pai-
sagem, foi utilizado o método de unidades de paisagem aplicado em
um trecho da cidade. Este artigo possui mapas de análise elaborados
para observar diferentes aspectos do trecho, com objetivo de auxiliar no
diagnóstico das unidades de paisagem existentes. Como ferramenta de
subsídio, foram estudados autores referência no tema de mapeamento
temático, assim como observação do local. Por fim, foram identificadas
as unidades de paisagem e apontadas suas características e potenciali-
dades.
Palavras-chave: Macaé. Unidades de Paisagem. Sistema de Espaços Livres. Paisagem Urbana.

\section{ABSTRACT}

The city of Macaé in the interior of the state of Rio de Janeiro, now has become known as the oil's national oil capital, received this title as it is an important management hub for the brazilian's Brazil's management of oil's activity. The interference of tThis activity has affected several city sectors of the city, such asboth in the economy, in population growth, in urban expansion and consequently in the landscape. With the interest aim in of characterizing the landscape, we used the landscape units method, to be applied in a stretch of significant importance to the city: the center. This article has analysis maps designed to observe different aspects of the section, with the purpose of assisting diagnosis of the existing landscape units. As a subsidy support tool, authors of reference were studied in on the this themetopic were studied and, thematic mapping, as well as site observation were conducted. Finally, the landscape units were identified and their characteristics were identified, as well as their potentialities, noted.

Keywords: Macaé. Landscape Units. Open Spaces System. Urban Landscape. 


\section{INTRODUÇÃO}

Ao longo dos anos, a cidade de Macaé sofreu brusca mudança das atividades econômicas com o advento da exploração do petróleo. O município tornou-se importante polo de administração desta nova atividade, atraindo muitos trabalhadores de outras regiões do país e do exterior. Dessa forma, o município se desenvolveu de modo crescente em curto espaço de tempo, gerando impactos significativos para os macaenses, novos moradores e demais agentes que usufruem do território de Macaé. Com isso, este trabalho pretende analisar as modificações na paisagem, em especial de sua área mais antiga, identificar os agentes geradores dessas transformações, assim como resgatar e registrar a memória do município.

Pretende-se com esta análise realizar uma leitura da paisagem no trecho de recorte do centro da cidade de Macaé-RJ, identificando e caracterizando as unidades de paisagem, com o intuito de resgatar as memórias do município. Para isso, foi necessário caracterizar o trecho definido para análise; realizar revisão bibliográfica sobre o tema; elaborar levantamentos, com visitas e observações do local, e mapas temáticos da área de estudo relacionados com aspectos morfológicos e socioeconômicos, identificando as unidades de paisagem por meio da sobreposição e análise dos dados e mapas.

\section{LocAlizAÇÃo e CARACTERIZAÇÃo dA ÁREA}

A área determinada para este estudo está localizada no município de Macaé, no estado do Rio de Janeiro (Figura 1). A $184 \mathrm{~km}$ da capital, atualmente a cidade é considerada a "Capital Nacional do Petróleo", por ser uma das sedes administrativas da Petrobras e importante polo no processo de exploração de petróleo do país. Além deste apelido, a cidade também era conhecida como "Princesinha do Atlântico", antes do crescimento das atividades petrolíferas (IBGE, 2010).

Com extensão territorial de $1.215,291 \mathrm{~km}^{2}$, o município de Macaé é composto por seis distritos: Macaé, Cachoeiros, Córrego do
Ouro, Frade, Glicério e Sana. Em 2010, de acordo com o Censo do IBGE, sua população estava em 206.728 habitantes, e em 2018 a estimativa era de 251.631, segundo o mesmo órgão. Caracterizase, assim, como uma cidade de médio porte.

O recente crescimento da cidade com as atividades petrolíferas a fez alvo de interesse de empresas dos ramos onshore e offshore, fazendo com que fosse reconhecida como local de oportunidade de trabalho. No entanto, a cidade possui outras vocações, principalmente originadas do suporte físico constituído pelos distritos serranos e suas cachoeiras, pelas praias, assim como pelo arquipélago de Santana (Figura 2) (CRESCIMENTO..., 2013).

\section{Referencial teÓRICO}

Para facilitar o entendimento deste estudo concebe-se necessário contextualizar o leitor acerca dos conceitos referentes ao que é paisagem e quanto à leitura das unidades de paisagem, dada a riqueza de modos de leitura que abrangem o tema.

De acordo com Macedo et al. (2016, p. 21), "a paisagem é constituída pela expressão morfológica da transformação do espaço físico face às mudanças sociais e/ou ambientais em um determinado espaço-tempo". Isto nos leva a entender que a paisagem é constituída de diversos elementos, entre eles o suporte físico. Porém, este não é o único elemento formador da paisagem, mas também as interações entre o indivíduo e o meio, consequências das relações sociais e da cultura. Outro fator importante para esta formação é o tempo, que age sob os elementos naturais e construídos, e também sobre o modo como o indivíduo se relaciona com a paisagem.

O método de leitura da paisagem por meio da identificação das unidades de paisagem auxilia na compreensão da paisagem sob aspectos e fenômenos que, aos olhos do segmento da arquitetura, são fruto das relações entre território e sociedade. Cabe ressaltar que outras áreas de estudo possuem estruturas de análise muito próximas, que, por vezes, podem ser associadas ao que se trata neste artigo. No entanto, esses segmentos da ciência 

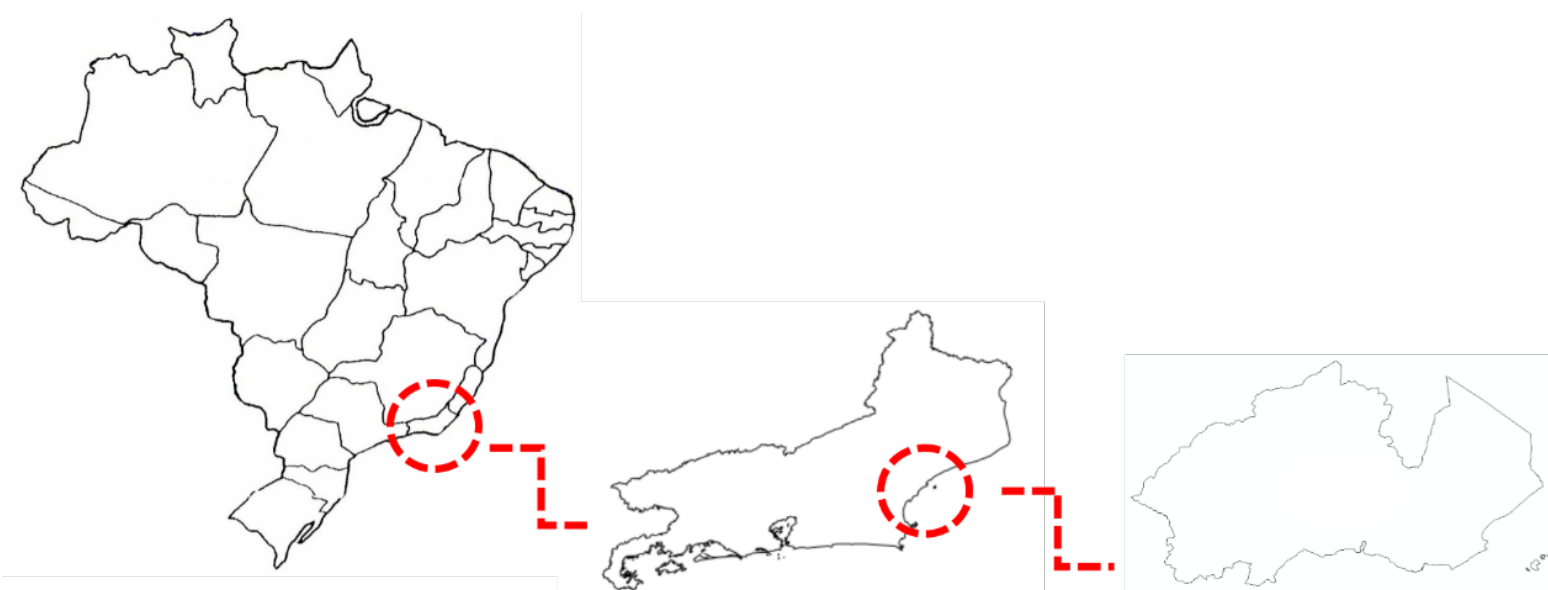

Figura 1 - Localização do município de Macaé.

Fonte: Pinhol (2012), adaptado pelas autoras.

BRASIL

ESTADO DO RIO DE JANEIRO

MUNICÍPIO DE MACAÉ

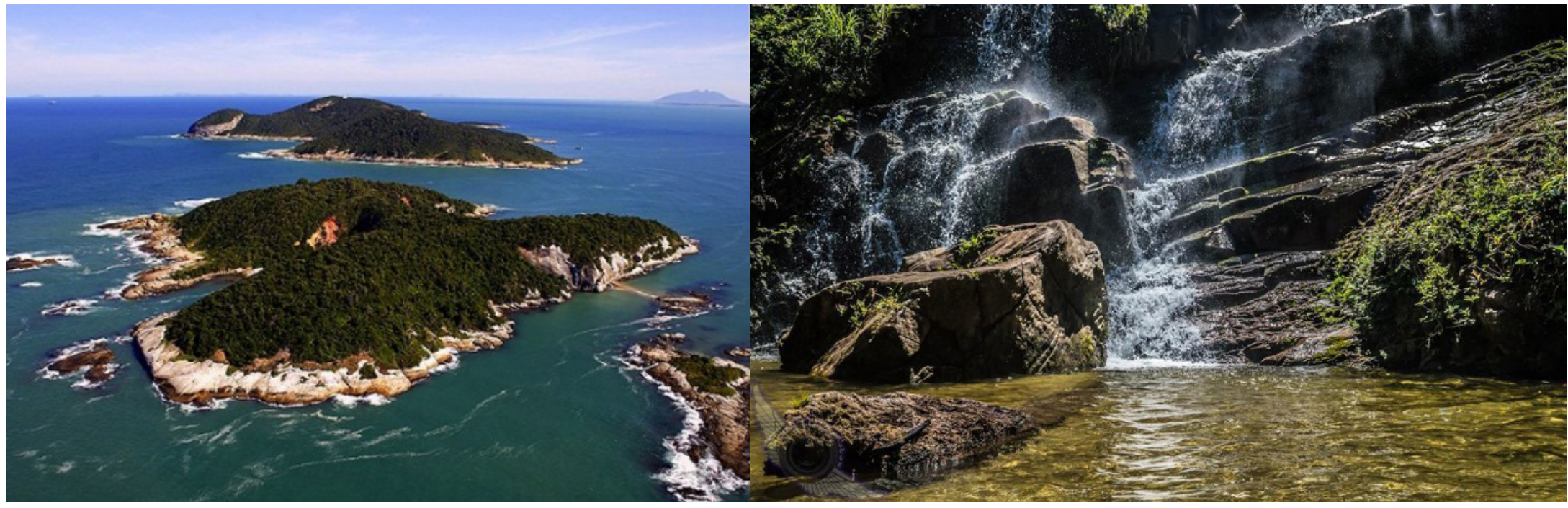

Figura 2 - Arquipélago de Santana e Cachoeira da Fortuna, Macaé-RJ. Fonte: Macaé Tips (2017). 
possuem diferentes conceitos sobre as dinâmicas da paisagem de acordo com seus respectivos vieses de estudo (SILVA, 2013).

As unidades de paisagem são divisões de uma determinada área categorizadas de acordo com um conjunto de características semelhantes. Os aspectos de homogeneidade dos locais podem ser definidos de acordo com diversas características, sejam elas físicas, urbanas ou ambientais. A partir desse método, é possível observar diferentes aspectos sobre o trecho, podendo cada unidade ser subdividida de acordo com o nível de detalhe de análise desejado (BRASIL, 2006).

O conceito de unidades de paisagem surge como ferramenta para auxiliar na compreensão dos espaços e das dinâmicas que o envolvem. Seu caráter é multidisciplinar, visto que a paisagem é resultado dos fatos sociais que a cercam. Por isso, seu olhar pode variar de acordo com a informação que se quer obter em dado momento. Como forma de ilustrar as vertentes que podem estar inseridas em uma unidade de paisagem, cabe citar o parcelamenos recursos hídricos e os espaços livres (SILVA, 2013).

Além disso, dentro da própria arquitetura pode se traçar distintos modos de leitura da paisagem de acordo com a necessidade da análise e com o objetivo de aplicação. Outro ponto importante a ser destacado é a escala do estudo, que pode variar também de acordo com o objetivo e influência de modo significativo no resultado a ser atingido. Aspectos essenciais para o propósito da pesquisa podem ser ressaltados ou mesmo ignorados de acordo com a escala utilizada; por isso, o destaque para este item (SILVA, 2013).

Observa-se que os limites definidos por instrumentos como legislação, por exemplo, não serão os mesmos utilizados para definir as unidades de paisagem. Estas consideram resultado das ações que agem sobre a paisagem, que não se limitam a divisões pré-estabelecidas. Como exemplo, a delimitação de bairros pode não ser a mesma da síntese das unidades de paisagem (MACEDO et al., 2016).

Outro termo importante para a compreensão deste trabalho é o de sistemas de espaços livres. Os espaços livres de edificação

podem ser públicos ou privados e estão diretamente relacionados com a qualidade do ambiente urbano. Isto porque são locais que atendem às demandas sociais por ambientes de convívio e lazer, além de ferramentas para o controle de questões sociais e ambientais das cidades brasileiras (MACEDO et al., 2016).

O conceito de espaços livres se apoia na ideia de integração entre os elementos que os compõem, visto que não funcionam de forma isolada, mas com elementos de integração entre eles, seja ela física ou não. Por isso são considerados um sistema. Incluise então os espaços livres de circulação, como ruas, avenidas, ciclovias, ferrovias e demais elementos que permitam o acesso a outros espaços livres, como os voltados ao lazer e ao convívio, a exemplo de praças e parques, e espaços livres de caráter ambiental, como os recursos hídricos e remanescentes florestais.

De acordo com Magnoli (2006, p. 144), o espaço livre de edificação é todo aquele que não possui cobertura, compreendendo a área urbana ou não, sendo ela natural, como cursos d'água e áreas dotadas de vegetação, ou pavimentada, incluindo os espaços de circulação. Além disso, pode compreender áreas tanto de domínio público quanto privado.

Por fim, destaca-se que a leitura da paisagem por meio de unidades de paisagem pode ter utilização prática de tal forma a ser norteadora de atuação de diferentes agentes transformadores da paisagem. Entre as aplicações possíveis estão os projetos paisagísticos, as políticas públicas, as revisões de legislação e o planejamento urbano em geral.

Neste estudo, será utilizada a leitura por meio de unidades de paisagem a partir da análise da construção da paisagem do município de Macaé. Isto se dará por meio de pesquisa sobre seu suporte físico, elaboração de mapas que auxiliem a compreensão dos dados referentes ao uso e ocupação do solo, aos tipos morfológicos e aos espaços livres de edificação públicos e privados. A partir desta leitura de dados, as unidades de paisagem serão classificadas e mapeadas como forma de sintetizar as informações obtidas. 


\section{EsTUdO DE CASO}

O recorte do trecho definido para este estudo (Figura 3) está localizado no centro da cidade, tendo como um dos eixos definidores a avenida Presidente Sodré, local de significante importância para o município. Isto se deve ao fato de ser uma significativa via da cidade, berço da ponte sobre o rio Macaé, além de abrigar a sede da Prefeitura e o Mercado Municipal de Peixes, uma das primeiras atividades econômicas do município.

Como limite do trecho no lado esquerdo do mapa, está situado o rio Macaé, curso d'água significativo para a cidade e sua paisagem, que contribui para a constituição dos espaços livres macaenses. O limitador identificado na parte inferior do mapa é constituído pela linha férrea e estação, que atualmente está desativada. Apesar disso, foi importante meio de circulação para escoamento da produção da região.

Por fim, o outro eixo de demarcação da área de estudo encontrase no limite da praça Veríssimo de Melo, significativo espaço livre público de convívio e lazer. A partir desta rua, as tipologias de uso e ocupação se repetem de modo considerável, o que neste caso não influenciam em novos dados para este estudo. Por isso, o limite do recorte foi definido no final da praça Veríssimo de Melo, seguindo até a linha férrea.

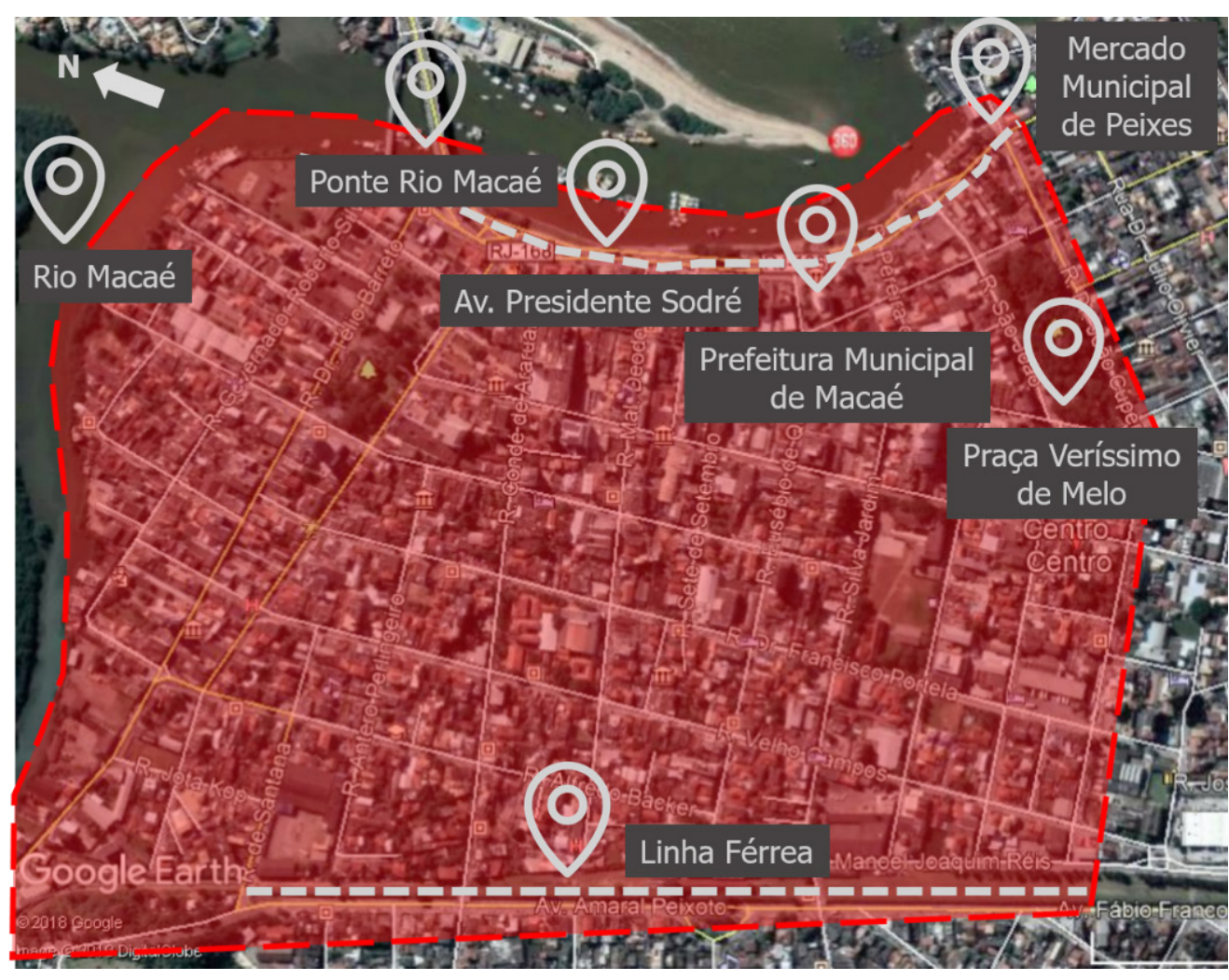

Figura 3 - Recorte de estudo. Fonte: Google Earth (2019), adaptado pelas autoras. 


\section{CONTEXTO HISTÓRICO dA ÁREA}

A praça Veríssimo de Melo (Figura 4) foi fundada em 1813 em área doada por uma família de renome da época. Conhecida como o pulmão da cidade, a construção da praça, que abriga árvores centenárias, deu-se através dos anos de modo gradativo. Inicialmente com pouca estrutura, a praça recebeu equipamentos urbanos como o obelisco, chafariz e coreto na década de 1910, assim como o busto em homenagem a Veríssimo de Melo em 2002. Outro fator importante sobre o local foi a instalação das grades na década de 1930, sob a justificativa de segurança (SIQUEIRA, 2008).

O Mercado Municipal de Peixes está em funcionamento em Macaé desde 1924, movimentando a economia da cidade ainda nos tempos de vila. O setor pesqueiro movimenta cerca de 5.000 trabalhadores com a venda de peixes, crustáceos e demais frutos do mar.
Em 28 de junho de 2018 foi inaugurado o novo prédio do Mercado (Figura 4), adequando-se às normas de acessibilidade e exigências da Agência Nacional de Vigilância Sanitária (Anvisa) e do Programa de Proteção e Defesa do Consumidor (Procon) (LISBOA, 2015).

A ponte Engenheiro Ivan Mundim (Figura 5), cujo nome é uma homenagem ao autor do projeto, é uma estrutura em concreto armado que liga o centro da cidade ao bairro da Barra. Inaugurada em 1978 e popularmente conhecida como "Ponte da Barra", a estrutura veio para substituir a ponte antiga, atualmente utilizada por pedestres e ciclistas. Em 2015, a Prefeitura apresentou um pré-projeto para duplicar a via, que atualmente conta com duas pistas, uma para cada sentido. Apesar disso, nenhuma obra de duplicação foi realizada até a data de produção deste artigo (FONTES, 2015).

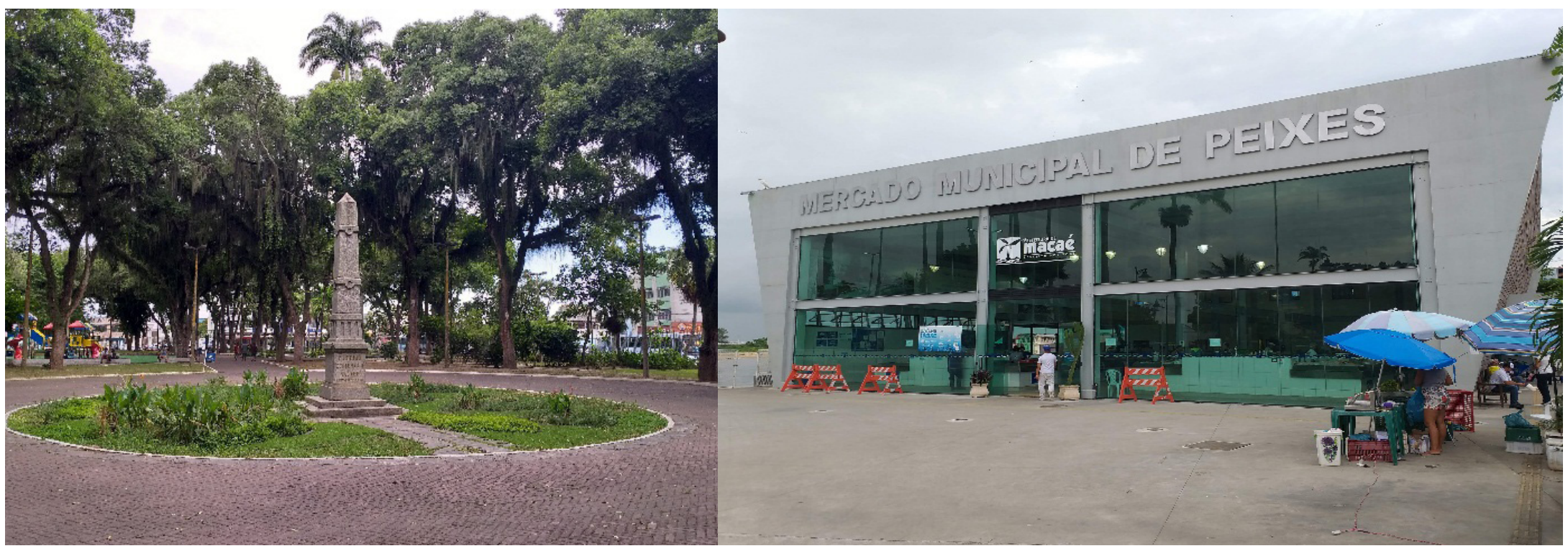

Figura 4 - Praça Veríssimo de Melo e Mercado Municipal de Peixes. Fonte: Acervo das autoras (2019). 


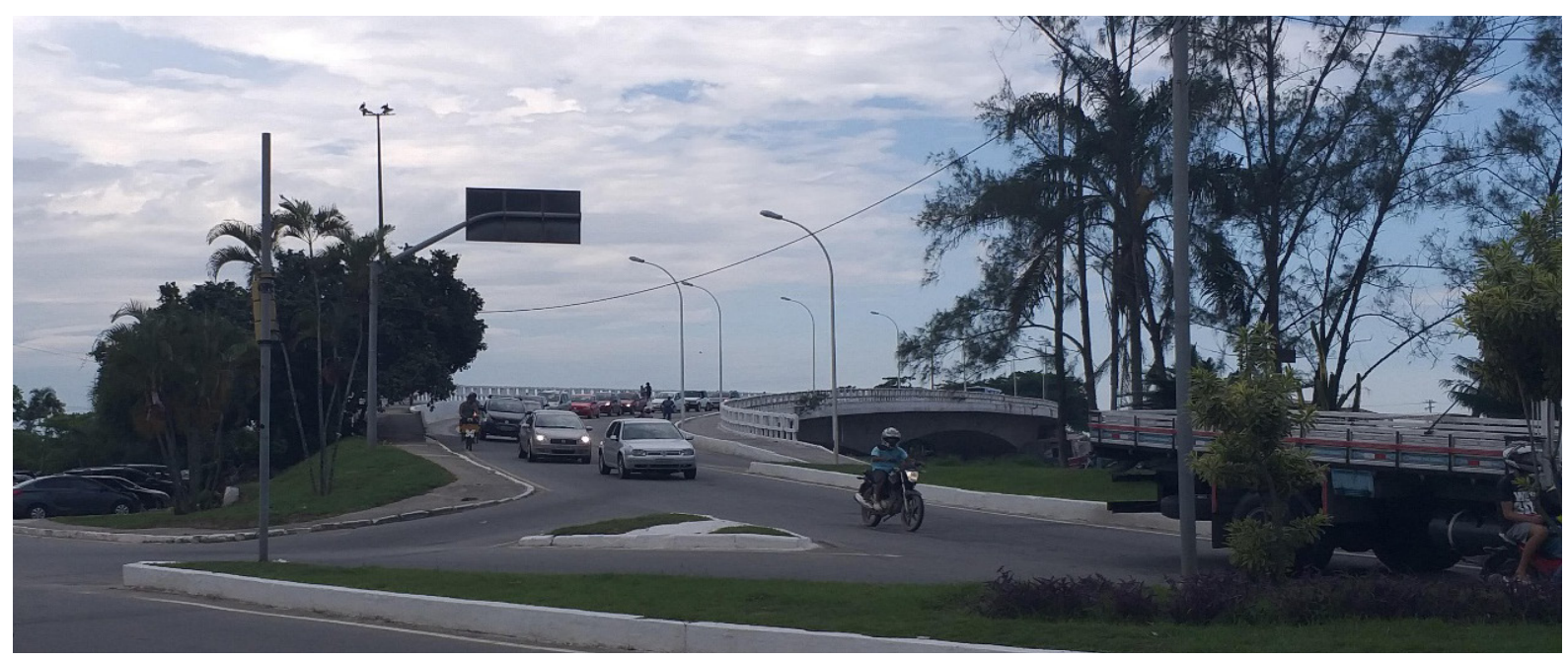

Figura 5 - Ponte Eng. Ivan Mundim. Fonte: Acervo das autoras (2019).

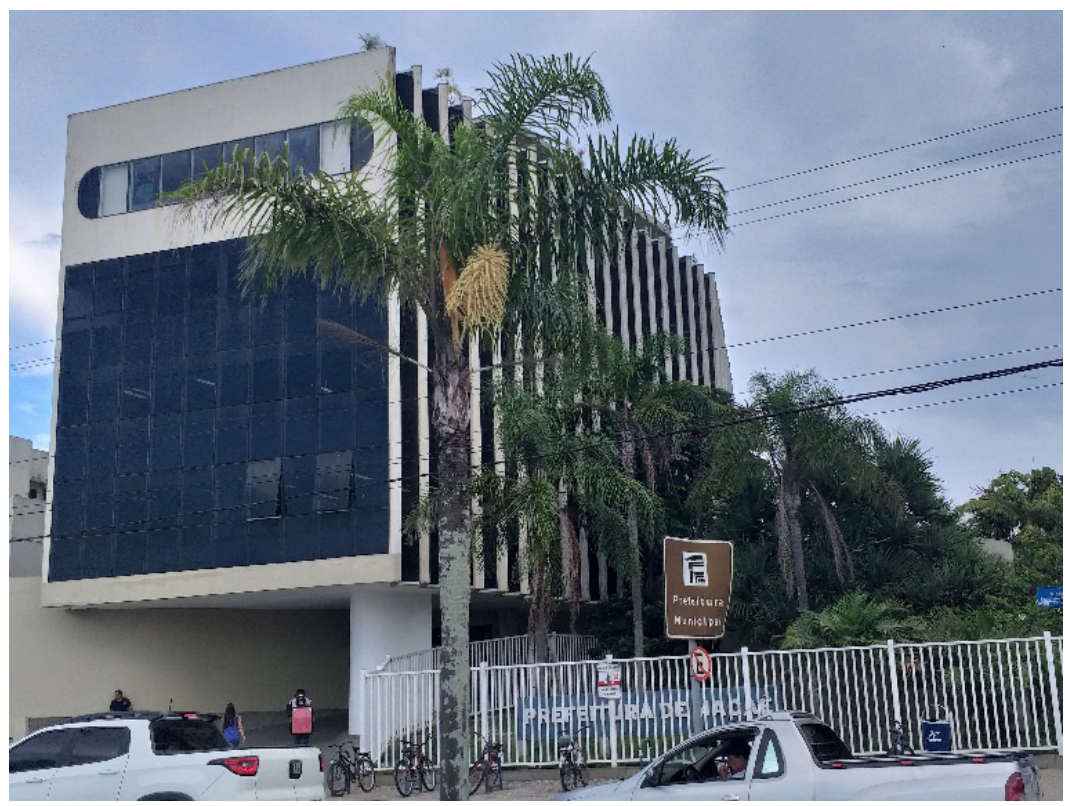

Figura 6 - Projeto Nova Sede da Prefeitura de Macaé. Fonte: Fundação Oscar Niemeyer (1985).

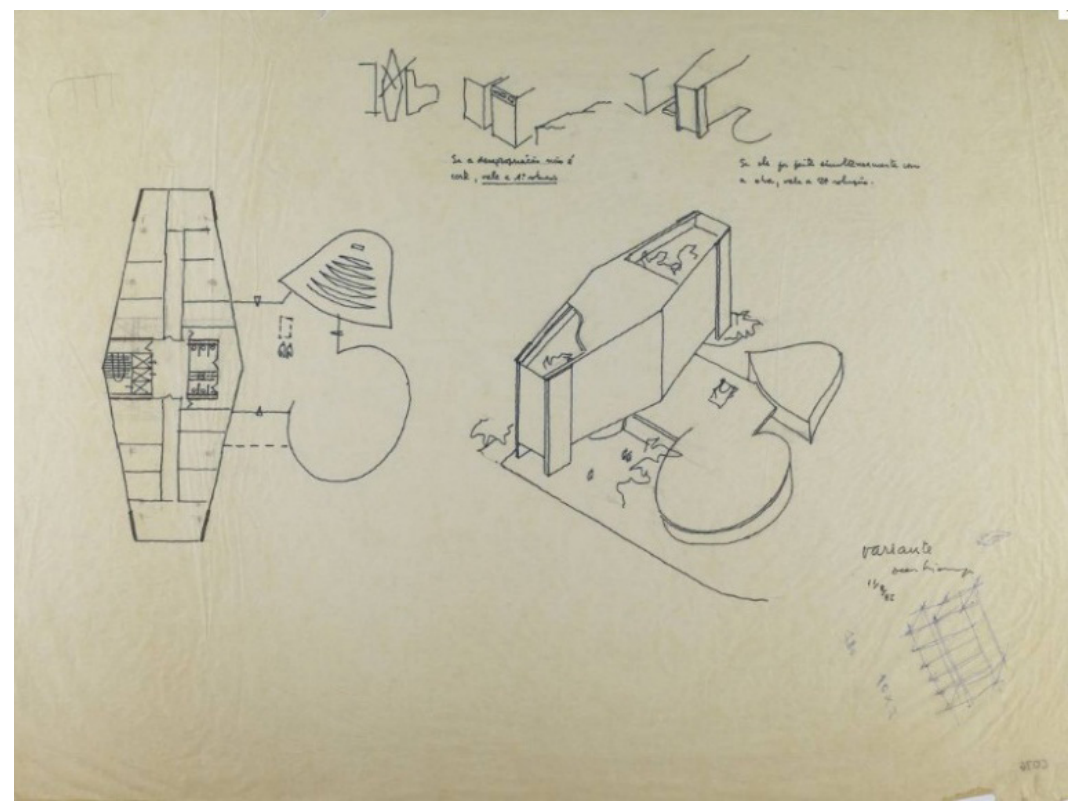

Figura 7 - Sede Prefeitura de Macaé. Fonte: Acervo das autoras (2019). 
A sede da Prefeitura de Macaé foi projetada pelo renomado arquiteto Oscar Niemeyer no ano de 1985 (Figura 6) a pedido do então prefeito da cidade, Alcides Ramos. Apesar disso, o prédio só foi inaugurado em 2004, após mais de uma década de paralisação das obras. O prédio (Figura 7) é composto por cinco pavimentos, sendo um deles enterrado, e, apesar de possuir cerca de $4.400 \mathrm{~m}^{2}$ de área construída, abriga apenas uma parte dos órgãos públicos da Prefeitura (SIQUEIRA, 2017).

A estrada de ferro do município de Macaé surgiu da necessidade de integrar o trecho Macaé-Campos. Essa ferrovia, também conhecida por "linha do litoral", foi construída por diferentes companhias no decorrer dos anos, que posteriormente foram agregadas pela Leopoldina. A implementação dos trilhos na cidade foi significativa para o escoamento da produção da região, gerando rapidez e segurança para os negócios da época. Além do transporte de carga, a linha férrea também foi significativa para a locomoção de passageiros, dada

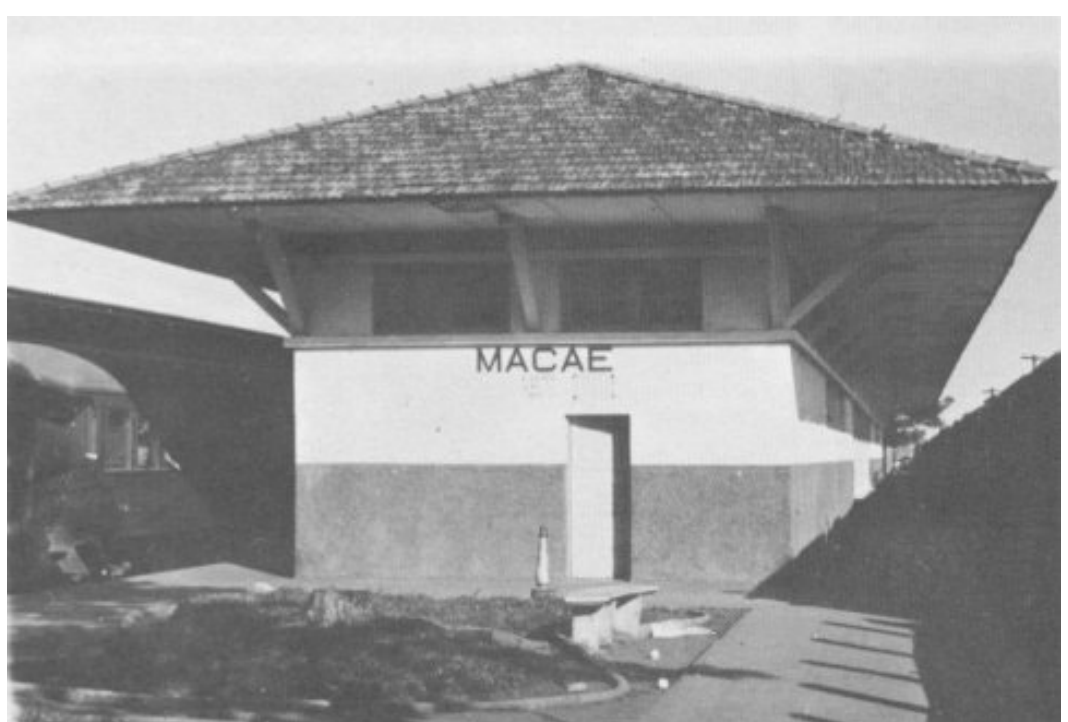

Figura 8 - Estação ferroviária de Macaé. Fonte: Giesbrecht (2018). a precariedade de outros meios de transporte existentes no período (Figura 8) (GIESBRECHT, 2018).

Existem algumas divergências quanto à data exata de implementação da estação ferroviária; no entanto, as hipóteses datam da década de 1870, e acredita-se que no ano de 1873 a linha já estava em operação.

Desse modo, esses importantes marcos para a constituição do cenário urbano do trecho escolhido foram gradativos, em diferentes séculos, e interferem na constituição da paisagem até os dias atuais.

Por fim, a Av. Presidente Sodré é uma importante via para o contexto histórico da área por diversos fatores, entre eles pode-se citar que é o único acesso à ponte que interliga a cidade, contém significativos prédios, como a sede da Prefeitura e o Mercado Municipal de Peixes, e margeia o curso d'água que até hoje é referência para os moradores da cidade.

\section{Mapas de ANÁlise}

Como ferramenta para a identificação das unidades de paisagens, foram elaborados mapas temáticos para dar suporte às análises deste estudo. O primeiro deles é o mapa de uso e ocupação do solo, no qual as quadras da área definida para análise foram categorizadas segundo a sua utilização (Figura 9).

O mapa da Figura 9 está classificado em seis categorias: roxo comércio e serviços; amarelo - serviços; verde-claro - residencial; rosa - misto comércio, serviços e residencial; vinho - institucional e residencial; e verde-escuro - espaços livres de convívio e lazer. A estratégia para elaboração deste mapa foi a análise predominante da atividade da quadra, sendo importante destacar que pode haver alguma outra categoria mesclada nas quadras; no entanto, não reflete a predominância nelas.

Através do mapa de uso e ocupação, pode-se observar a influência da rua Dr. Télio Barreto e da Av. Rui Barbosa para a distribuição das tipologias de uso. Elas se mostram eixos centralizadores 
da tipologia predominante, que a partir delas se diluem nas outras menos predominantes.

O mapa de espaços livres públicos (Figura 10), por sua vez, destaca as informações relativas aos espaços não edificados, sejam eles de convívio, lazer, ambientais ou de circulação. A classificação para elaboração do mapa foi: em laranja-escuro estão identificadas as vias de circulação de carros, pedestres e ciclistas. $\mathrm{Na}$ cor laranja-claro está representada a área de circulação da linha férrea e estação ferroviária, atualmente desativadas.
Nos trechos em verde-escuro estão destacados os espaços livres institucionais, assim como em verde-claro são as áreas representadas pelos espaços livres de convívio e lazer. Por fim, em azul está destacado todo o trecho no qual os recursos hídricos podem ser identificados.

As vias destacadas no mapa anterior possuem, em sua maioria, pavimentação asfáltica, que necessita de reparos em alguns trechos, devido ao alto fluxo de veículos que circulam diariamente pelo local. As calçadas, por sua vez, possuem larguras irregulares

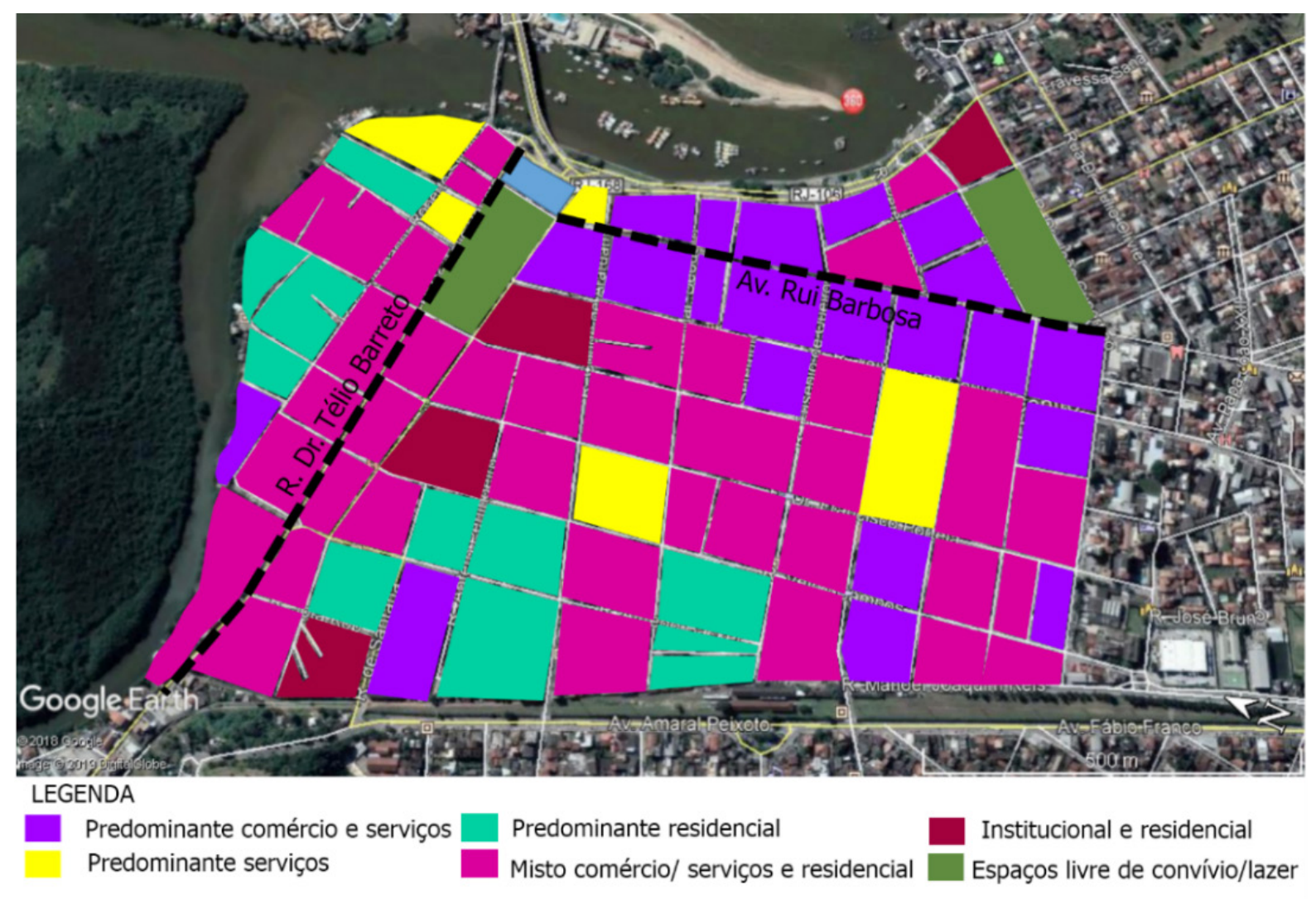

Figura 9 - Mapa de uso e ocupação. Fonte: Google Earth (2019), adaptado pelas autoras. 


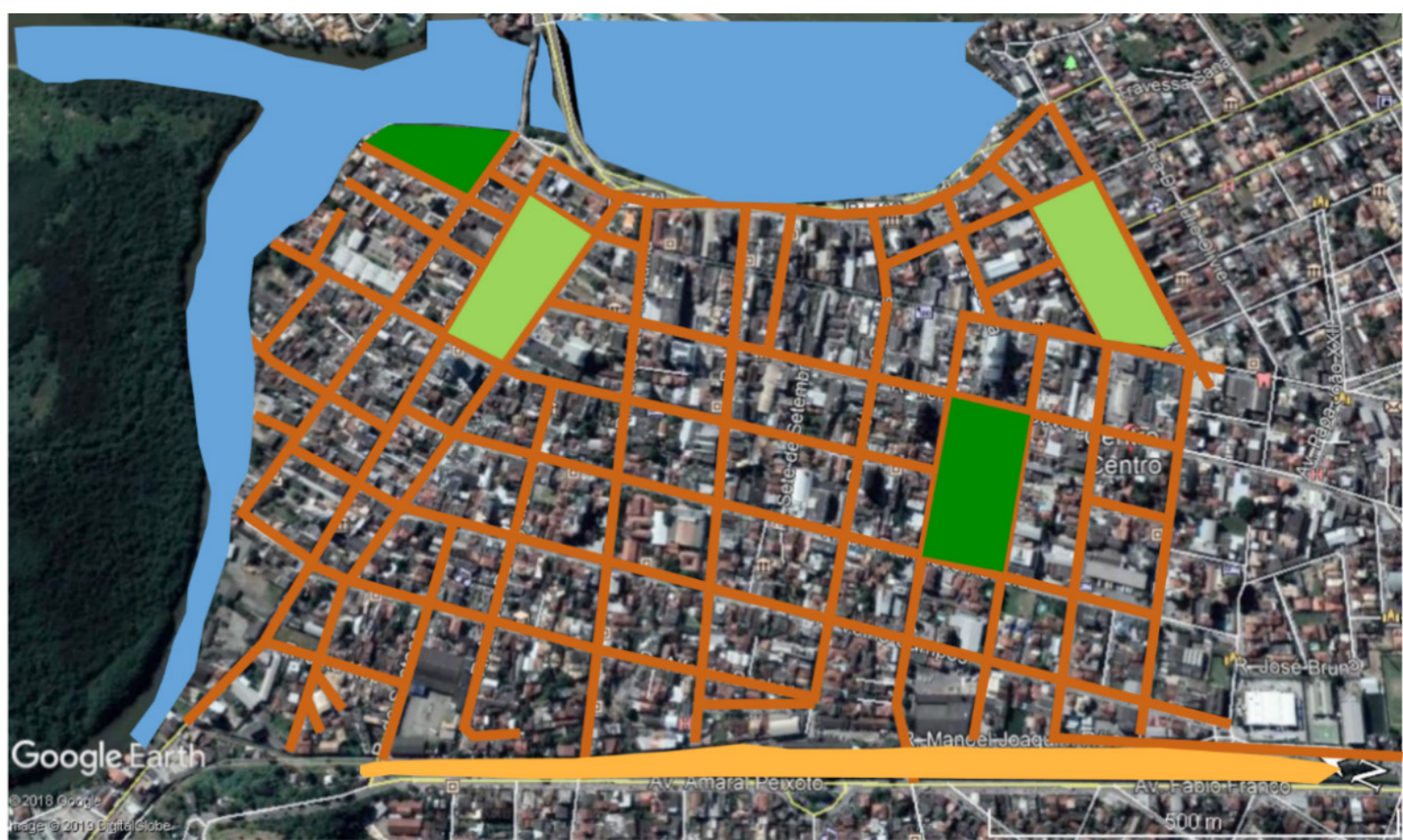

LEGENDA

Cursos d'agua

Espaços livres institucionais ferroviário
Espaço livre de circulação
Espaços livres de lazer e convívio Espaços livres de circulação rodoviários e pedestres
Figura 10 - Mapa de espaços livres públicos.

Fonte: Google Earth (2019), adaptado pelas autoras. de acordo com os trechos. Um fator importante a ser considerado foi o grande crescimento da cidade desde a década de 1970, com a implantação da Petrobras no município, o que culminou no aumento do fluxo de veículos e pedestres no centro da cidade. Por isso, considera-se as calçadas insuficientes para a demanda atual de pedestres, gerando gargalos em diferentes pontos do centro.

Não somente as calçadas são alvo deste afunilamento, mas também as vias, que têm sua fluidez comprometida, principalmente em horários de pico. A arborização das vias também não é notada de modo considerável, ao contrário, quando existentes, até comprometem a circulação de pessoas, visto que ocupam espaço nas calçadas, que, por sua vez, não foram dimensionadas para o fluxo de pedestres atual.

Uma intervenção recente que afeta a dinâmica dos veículos no centro foi a implementação dos parquímetros, que regulam o estacionamento de veículos nas vagas das principais vias. Os automóveis podem permanecer por no máximo duas horas na vaga. Após esse período, o condutor deve retirar seu veículo, podendo estacioná-lo em outro local, também pelo período máximo de duas horas, assim sucessivamente. Este é um instrumento regulador do fluxo de veículos, o que gera impacto na dinâmica dos 
usuários do local, por exemplo, incentiva o surgimento de estacionamentos particulares. Além disso, também se torna necessário considerar outros meios de transporte, pois muitos precisam permanecer por tempo superior ao permitido pelo parquímetro (CONDUTORES..., 2016).

O mapa da Figura 10 também revela a existência de dois espaços livres públicos de convivência e lazer, sendo eles as duas principais praças da cidade: Washington Luiz e Veríssimo de Melo. A praça Washington Luiz, nomeada em homenagem ao macaense que se tornou presidente da República, é um dos pontos mais arborizados do centro, que também possui outras modalidades de equipamentos urbanos, como academia, quadra de esportes com arquibancada e banheiros. Esta praça também conta com grande área livre pavimentada, que permite diferentes utilizações ao longo do ano, como abrigo temporário para pessoas em situação de rua no inverno, cinema na praça, campanhas temáticas de conscientização e ônibus literário.

A praça Veríssimo de Melo, como citado anteriormente, é considerada o pulmão da cidade, abrigando árvores frondosas. Também possui alguns equipamentos urbanos, como parque infantil e área para montagem de estruturas itinerantes, como a tradicional feira de produtos artesanais semanal, a exposição de flores e a festa do padroeiro da cidade.

Durante a produção deste artigo, foi possível observar que as praças têm servido de suporte para pontos de integração do transporte coletivo enquanto acontece a reforma no terminal central da cidade.

No que se refere aos recursos hídricos da área de estudo, o rio Macaé, identificado na margem esquerda do mapa (Figura 3), é alvo de poluição. Frequentemente, são despejados lixos e dejetos em seu leito. Já no trecho que circunda a Av. Presidente Sodré, são identificadas na paisagem embarcações pesqueiras em direção ao Mercado Municipal de Peixes. Apesar de estarem em locais próximos, o modo como as orlas no trecho esquerdo do mapa e ao longo da Av. Presidente Sodré são tratadas é bem distinto. $O$ primeiro trecho faz fronteira com as residências, sem afastamento necessário dos recursos hídricos, além de ser subutilizado (Figura 11). O segundo, por sua vez, possui equipamentos urbanos como passeio largo, canteiros e arborização.

Através da observação do trecho do centro da cidade de Macaé, pode-se constatar que ela reflete a realidade de muitas outras cidades brasileiras. Os espaços livres privados, que em geral são aqueles internos ao lote, de propriedade privada, estão cada vez mais escassos, o que muitas vezes se deve à necessidade de expandir a área construída para atender às demandas de moradia e de serviços.

Neste caso, o fato de o centro ser uma área consolidada e abastecida de serviços básicos contribui para o adensamento. Cabe também ressaltar o fator cultural da questão, que se reflete na escassez de elementos naturais e de áreas permeáveis, que contribuem para os problemas urbanos como o de drenagem.

Isso acentua a demanda por espaços livres de lazer e convívio, importantes para a manutenção das dinâmicas sociais. Como afirma Macedo et al. (2016), o sistema de espaços livres é essencial para as cidades, pois contribui para a vida cotidiana, colabora para a construção da paisagem urbana, auxilia na vida pública e privada e abriga importantes elementos ambientais.

No entanto, no que se refere aos espaços livres privados, a existência deles nas quadras do trecho escolhido para a análise ficam na faixa de 0 a $30 \%$ da área da quadra. Os elementos que costumam compor as áreas não edificadas privadas, como quintais, pátios internos, afastamentos frontais e laterais, não são marcantes nesta área por uma questão histórica. O centro da cidade possui construções mais antigas, que, por sua vez, foram edificadas em períodos nos quais os elementos de regulação urbana não contemplavam estas ferramentas ou nem existiam.

\section{TIPOS MORFOLÓGICOS}

Quanto às edificações existentes na área estudada, foram identificados e mapeados sete tipos morfológicos, descritos a seguir e apontados no mapa da Figura 19. Do mesmo modo que o mapa 


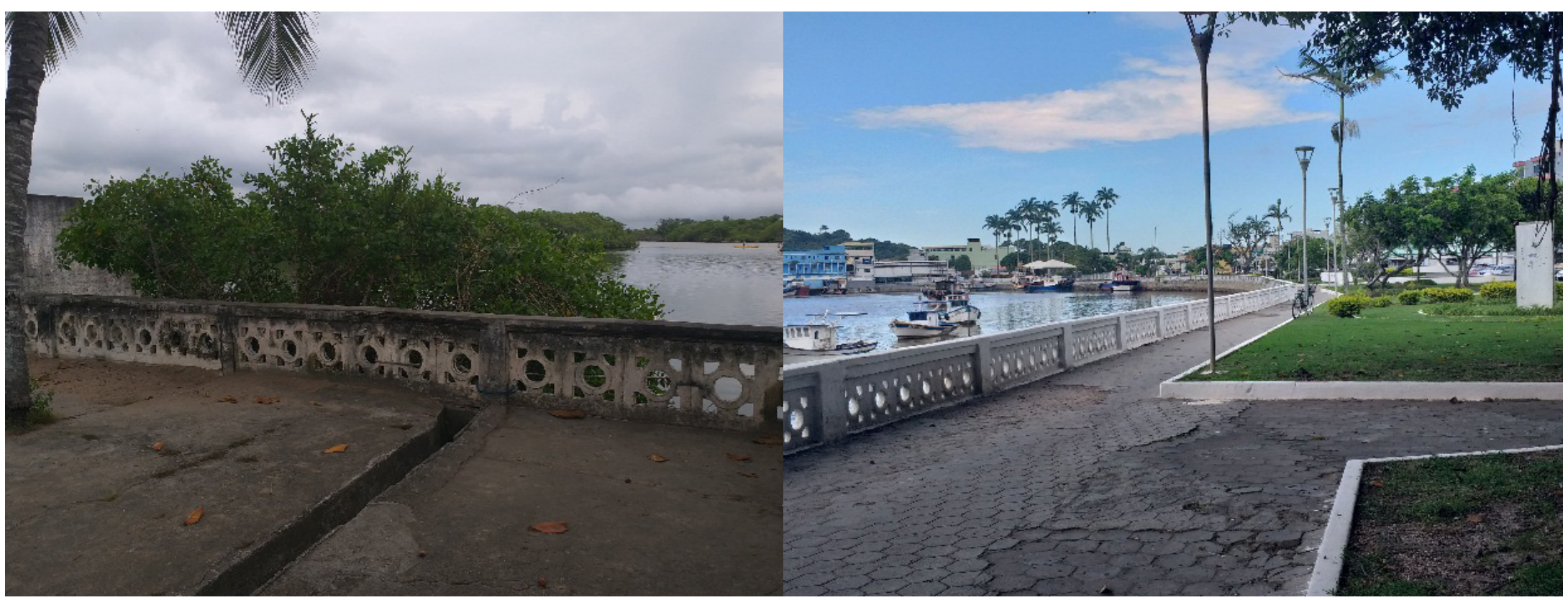

Figura 11 - Disparidade das orlas.

Fonte: Acervo das autoras (2019).

de uso e ocupação do solo, na elaboração deste mapa levou-se em consideração a predominância da quadra.

Tipo 1 - Ocupação horizontal consolidada: quadras compostas por edificações, predominantemente horizontais, de até quatro pavimentos, em área urbana consolidada. Espaços livres em pouca quantidade, formados pelos afastamentos frontais e laterais, quando existentes (Figura 12).

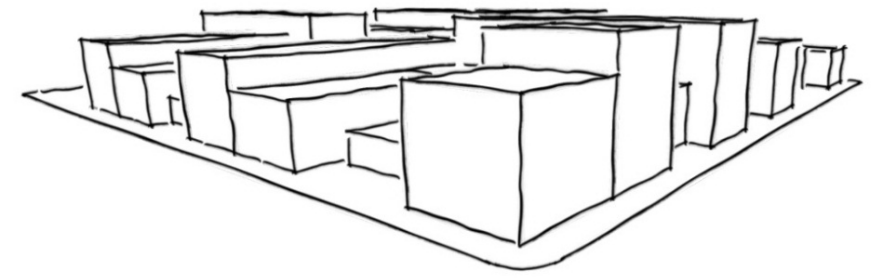

Figura 12 - Tipo morfológico 1 .
Tipo 2 - Ocupação horizontal mista: quadras com edificações horizontais de até dois pavimentos com espaços livres consideráveis. Parte da quadra é formada por terrenos baldios gerados por demolições (Figura 13).

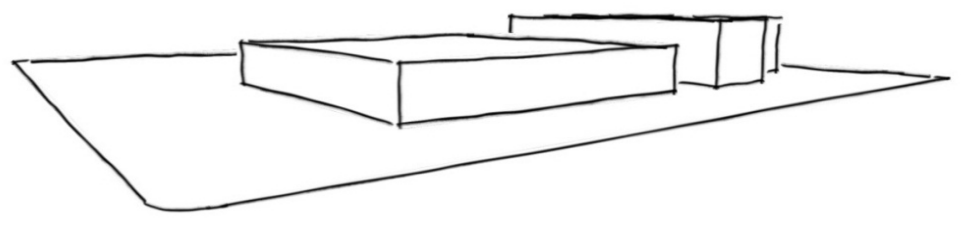

Figura 13 - Tipo morfológico 2.

Tipo 3 - Ocupação horizontal de transição: quadras consolidadas 
com edificações predominantemente compostas por quatro pavimentos; no entanto, surgem novos elementos. Estes são formados por construções a partir de cinco pavimentos, que apesar de serem em menor número, afetam a dinâmica da área por possuírem maior densidade de utilização devido ao aumento de área construída, além de alterarem a paisagem existente (Figura 14).

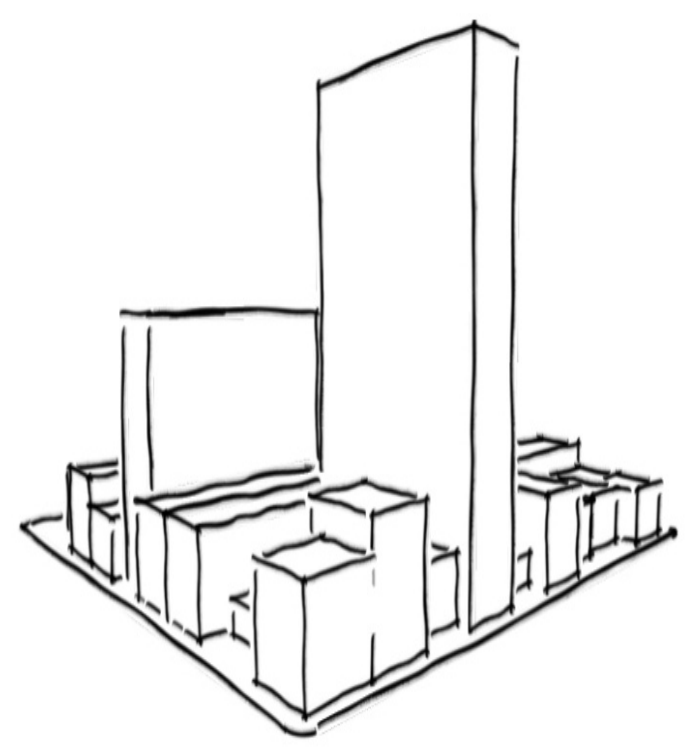

Figura 14 - Tipo morfológico 3.
Tipo 4 - Áreas de convivência e lazer: espaços livres públicos dotados de equipamentos urbanos (bancos, academia, banheiros, parques infantis, quadras) e áreas verdes (árvores e canteiros) (Figura 15).

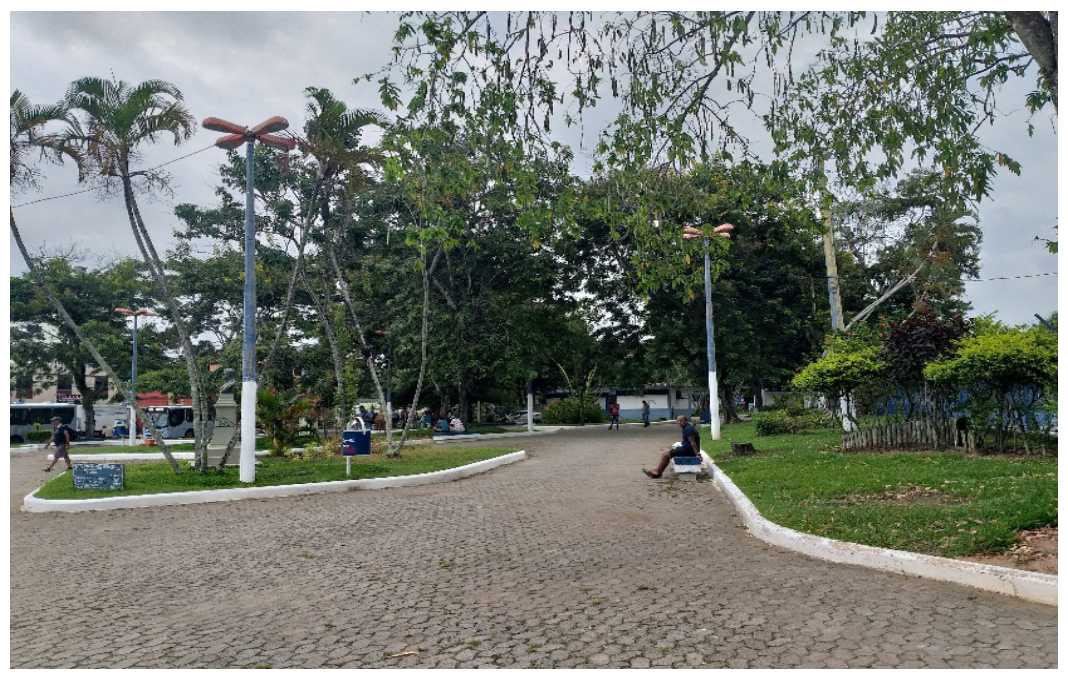
Fonte: Acervo das autoras (2019). 
Tipo 5 - Ocupações consolidadas mistas: quadras estruturadas com construções horizontais e verticais em proporções semeIhantes. Assim como citado anteriormente, os espaços livres são escassos nessas áreas, formados, quando existentes, por afastamentos ou pequenos quintais (Figura 16).

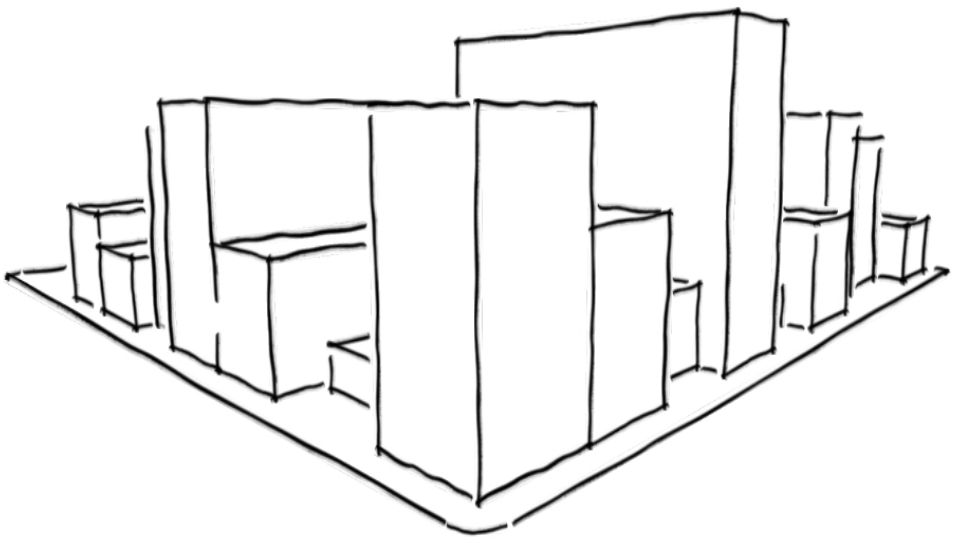

Figura 16 - Tipo morfológico 5.
Tipo 6 - Encrave natural: barreira à expansão da mancha urbana formada por elemento da natureza que limita o crescimento urbano, constituindo espaço livre público. Neste caso, o curso d'água do rio Macaé (Figura 17).

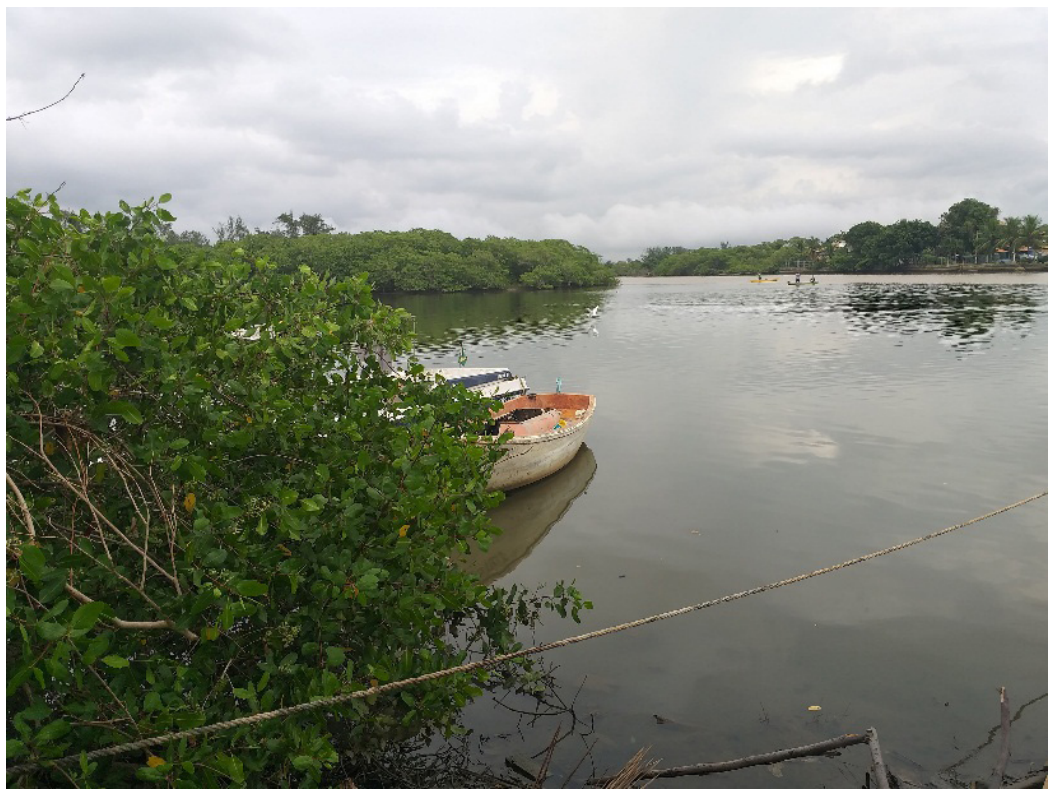

Figura 17 - Rio Macaé. Fonte: Acervo das autoras (2019). 
Tipo 7 - Encrave urbano: barreira à expansão da mancha urbana criada por elementos urbanos, que também interferem no crescimento urbano. Constituído pela linha férrea e estação, atualmente desativados. Possui elementos construídos, no entanto, predominantemente de espaço livre público (Figura 18).

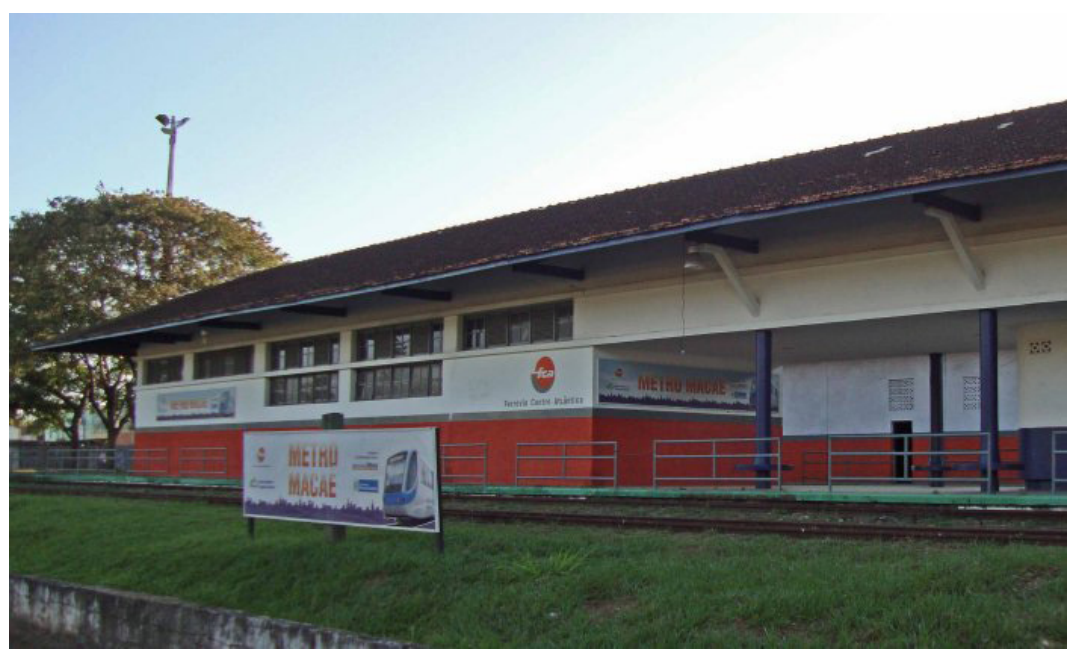

Figura 18 - Estação ferroviária.

Fonte: Giesbrecht (2018).

Seguindo as classificações assinaladas anteriormente, o mapa da Figura 19, sintetiza de forma gráfica as informações coletadas de acordo com os sete tipos morfológicos.

Pode-se visualizar no mapa da Figura 19 as barreiras de expansão formadas pelos tipos 6 e 7, encraves natural e urbano respectivamente. Além disso, a importância que o tipo 4, espaços livres de convivência e lazer, exerce no tecido urbano demonstra a resistência dos espaços livres públicos.

Além disso, é possível identificar que a os tipos 3 e 5, com tendência à verticalização, estão mais próximos à Av. Presidente Sodré, que se mostra importante vetor de expansão urbana. Em contrapartida, o tipo 2, identificado por possuir mais espaços livres, está posicionado nas bordas da área estudada. Por fim, o tipo 1, quadras horizontais, permeia todo o mapa.

\section{Classificação das unidades de paisagem}

Após a sobreposição dos mapas de análise e da contextualização observada na área, foram identificadas seis unidades de paisagem (UP) na área de estudo, apresentadas no mapa da Figura 20.

Unidade de paisagem 1: quadras predominantemente com característica morfológica horizontal, crescimento urbano limitado pelo rio. As edificações confrontantes com o rio não possuem afastamento, assim como inexistência de orla tratada. O traçado das quadras e suas dimensões possuem padrões irregulares e os tipos de uso da unidade se dividem em quadras residenciais e de comércio e serviços. As vias de acesso ao local são pavimentadas e o fluxo de veículos é moderado. A dimensão das calçadas é compatível com a demanda de pedestres e não há ciclovia. A cobertura vegetal é existente em locais pontuais; no entanto, não é característica predominante.

Unidade de paisagem 2: esta unidade de paisagem tem como eixo uma importante via de acesso aos bairros próximos, denominada rua Dr. Télio Barreto. A partir dela é possível observar que os usos predominam nas quadras de modo misto residencial e comércio e serviços. O traçado das vias, com pavimentação em asfalto, apresenta traçado perpendicular e quadras com dimensionamento mais regular. Nesta unidade está inserido um significativo espaço livre público, que é a praça Washington Luiz, dotada de equipamentos urbanos e considerável cobertura vegetal formada por árvores e canteiros. Os tipos morfológicos que compõem essa unidade são predominantemente horizontais e já são identificadas quadras com construções mais verticalizadas, assim como quadras com espaços livres maiores, posicionadas nas extremidades da mancha.

Unidade de paisagem 3: o elemento estruturador da paisagem é o curso d'água, canal de comunicação entre as embarcações e o Mercado Municipal. Possui orla trabalhada com equipamentos 


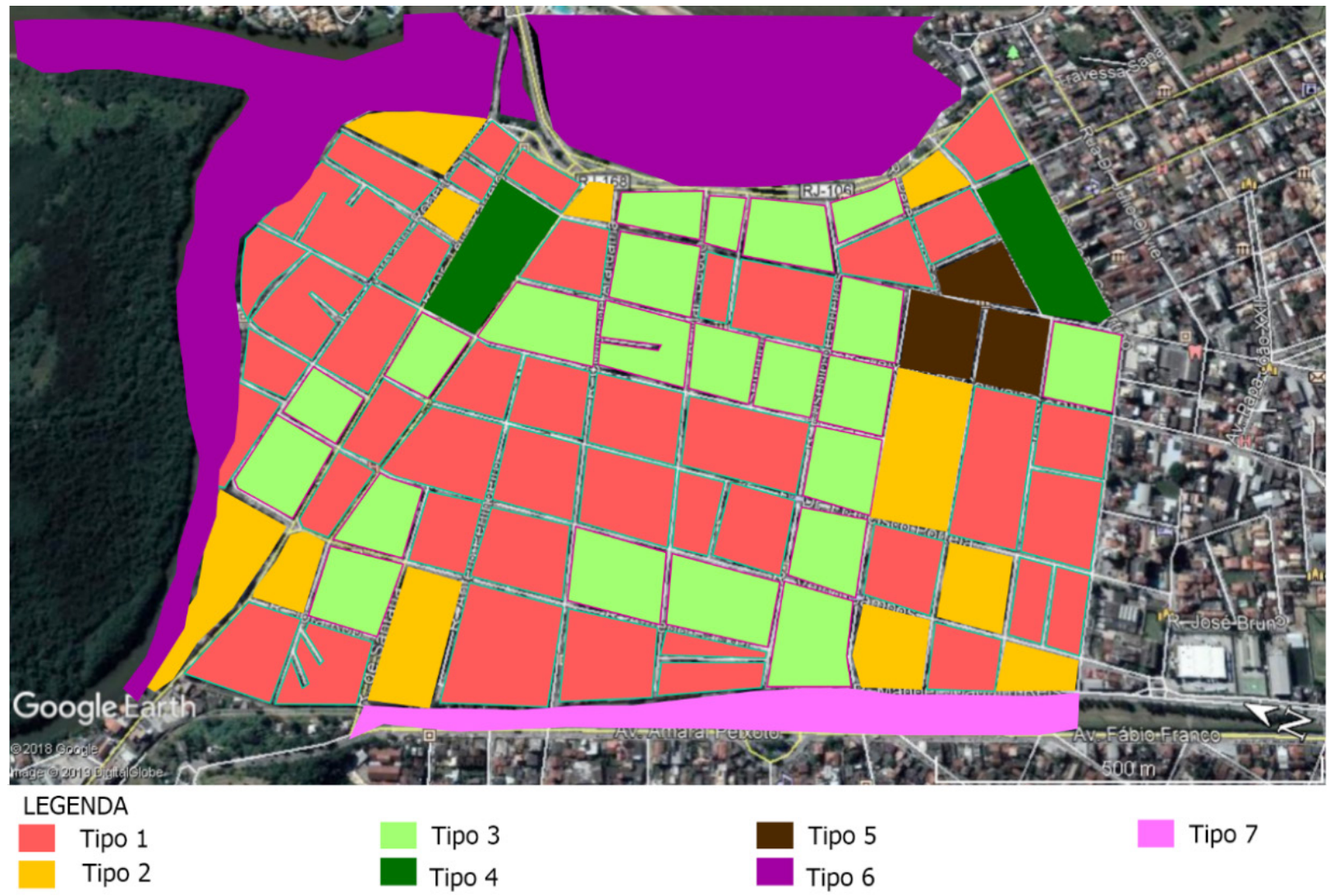

Figura 19 - Mapa de tipos morfológicos.

Fonte: Google Earth (2019), adaptado pelas autoras.

urbanos e cobertura vegetal consistente que contribui positivamente para a paisagem. Junto à orla, a Av. Presidente Sodré faz a ligação dos veículos com a ponte Ivan Mundim, elemento estruturador da mobilidade da cidade. Outra expressiva via para os munícipes é o calçadão da Av. Rui Barbosa, um dos principais pontos de comércio e serviços de Macaé. O traçado da mancha urbana possui formas irregulares, que, quanto mais se aproximam da orla, tomam a forma do curso d'água. Sem dúvida é a unidade com maior cobertura vegetal do estudo, isto por contemplar a praça Veríssimo de Melo, que, como citada anteriormente, é uma das poucas áreas de espaço livre com vegetação ainda resistente. Apesar disso, a mancha desta unidade é a que possui maior variedade de tipos morfológicos, sendo área de

tendência à verticalização das construções.

Unidade de paisagem 4: centralizada na área de estudo, possui apenas duas tipologias morfológicas, que se dividem em proporções equilibradas entre horizontal e horizontal com construções verticais pontuais. Seu traçado urbano é irregular, assim como o tamanho e proporção das quadras. Este é um dos poucos trechos da cidade que possui ciclovia, localizada na rua Teixeira de Gouveia, uma via que, assim como as outras, possui pavimentação asfáltica. Por vezes, é possível observar gargalos no fluxo de pedestres das calçadas, que são intensamente utilizadas devido ao polo atrativo comercial. A cobertura vegetal neste trecho é pequena, devido ao alto adensamento urbano. 
Figura 20 - Mapa das unidades de paisagem. Fonte: Google Earth (2019), adaptado pelas autoras.

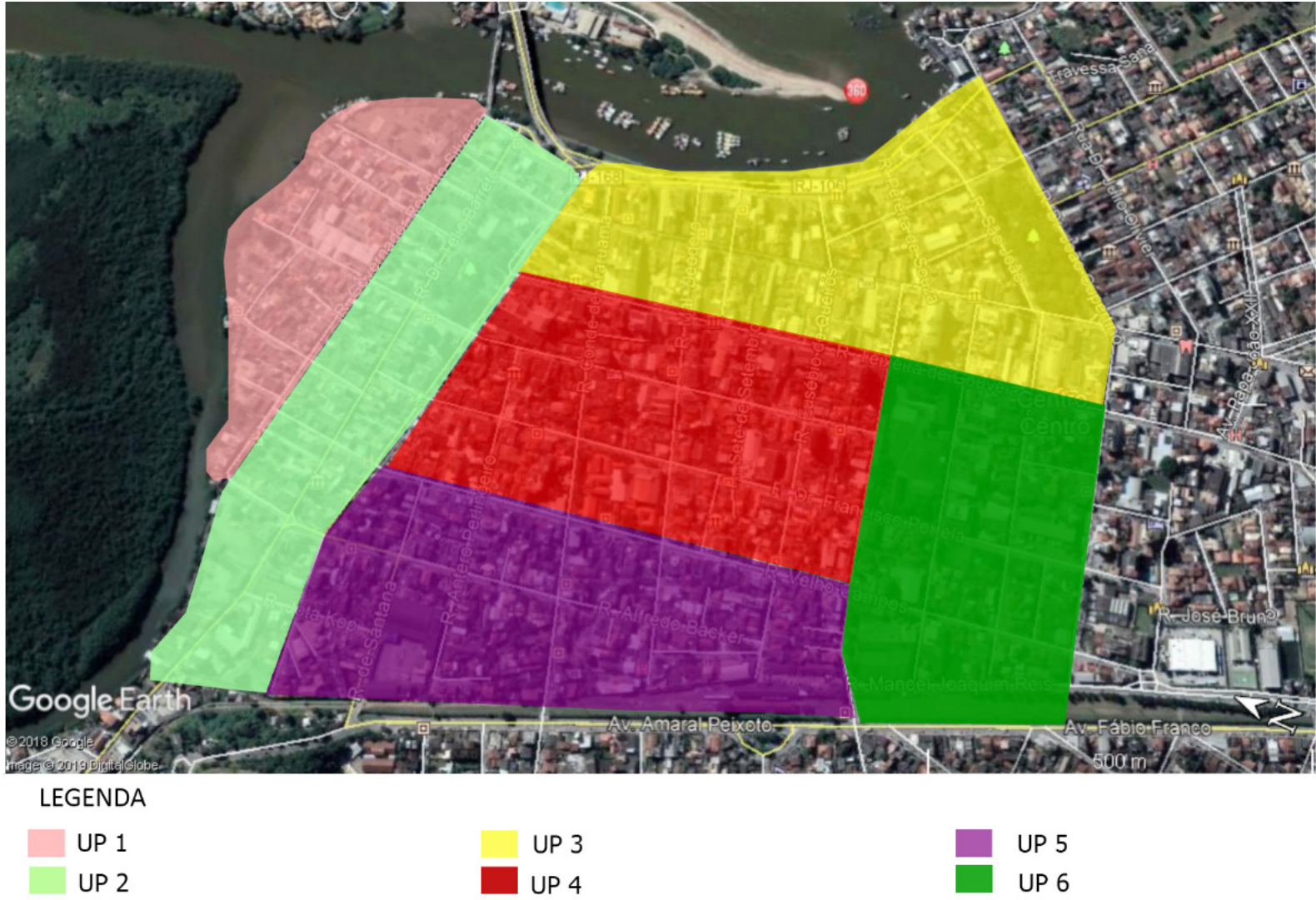

Unidade de paisagem 5: caracterizada por traçado urbano e quadras irregulares, esta unidade também possui obstáculo ao crescimento: a linha férrea. O tipo morfológico predominante é o horizontal, com alguns pontos de verticalização. Os usos são diversificados, destacando-se o uso residencial e misto residencial com comércio/serviços. As vias de automóveis são asfaltadas e a cobertura vegetal, por sua vez, é escassa.

Unidade de paisagem 6: nesta unidade se destaca o traçado perpendicular da rua, assim como a utilização predominante pelo setor de comércio e serviços. Outra característica importante é em relação aos tipos morfológicos, sendo esta uma das poucas unidades onde há quadras mistas com gabaritos proporcionais verticais e horizontais, paradoxalmente às também existentes quadras menos adensadas e de perfil horizontal. No que tange às ruas, cabe citar a rua Vereador Manoel Braga, via que leva o fluxo de veículos em direção à ponte, tornando-se eixo no que se refere aos usos.

\section{Conclusão}

Conforme a sobreposição dos mapas e dados obtidos da área, observa-se que o centro possui adensamento urbano de crescimento exponencial em curto prazo, devido à modificação ocor- 
rida na cidade com o advento da extração de petróleo na região. Assim, alguns aspectos urbanos não foram dimensionados para se adequar às novas demandas geradas, aliado à falta de espaço físico para expansão - alguns pontos de obstrução são frequentes no que se refere ao fluxo de pessoas e veículos. Além disso, cabe ressaltar o valor histórico existente nessa área, que contém elementos seculares significativos para a cidade, utilizados até hoje.

Isso é de extrema importância, dado o fato de que a possibilidade de conseguir espaços significativos para implantação de espaços livres de lazer e convivência, por exemplo, são pequenas, pois a tendência é de que o adensamento da mancha urbana seja cada vez mais intenso, assim como o processo de verticalização das construções. Essa modificação pode ser regulada por instrumentos urbanísticos garantidos por lei. De acordo com a Lei Complementar n 141/2010, que delibera sobre o Código de Urbanismo do Município de Macaé, a área analisada está inserida na Zona de Uso Diversificado 7, com parâmetros urbanísticos de coeficiente de aproveitamento 4, taxa de ocupação de $70 \%$, dimensão mínima do lote de $200 \mathrm{~m}^{2}$ e testada mínima de $10 \mathrm{~m}$, compreendendo uma das mais permissivas do município (MACAÉ, 2010).

As ruas e calçadas possuem capacidade limitada de alargamento, o que gera conflito na fluidez do transporte para a atual de- manda; caso ela aumente, o direito de ir e vir será ainda mais comprometido. Por isso, pondera-se que a escassez de espaço disponível para expansão urbana é um fator crítico nesta área.

Pode-se constatar também que o suporte físico referente aos recursos hídricos da região é abundante, tratados, porém, de modo muito distinto. Por um lado, o rio não é respeitado em seus afastamentos e é ignorado, sendo alvo de marginalização e falta de preservação. Por outro, é intensamente usado para fomentar o setor pesqueiro, que perdura no município há muito tempo e promove um certo cuidado paisagístico no rio. No entanto, este recurso natural da cidade não é explorado em seu total potencial, sendo assim um alerta de potencialidade para o município, que, devido à crise do petróleo que atingiu o país nos últimos anos, busca retomar suas origens e explorar outras virtudes.

Além dos aspectos físicos aqui analisados, outro elemento fundamental na construção da paisagem são os hábitos e cultura do local. Como citado anteriormente, os habitantes da cidade se mostram interessados em alternativas para recuperar a história da cidade, ressignificando espaços possivelmente esquecidos. Por isso, justifica-se a busca pelo papel simbólico e, consequentemente, a memória do centro da cidade, que expressa uma fundamental significação da história macaense. 


\section{ReferênCIAS Bibliográficas}

BRASIL. Ministério do Meio Ambiente. Projeto orla: fundamentos para gestão integrada. Brasília, DF: MMA, 2006

CONDUTORES devem respeitar regras de estacionamento na área do Rotativo. Prefeitura de Macaé, 11 nov. 2016. Disponível em: http://www.macae.rj.gov.br/noticias/leitura/noti $\mathrm{cia} /$ condutores-devem-respeitar-regras-de-estacionamento-na-area-do-rotativo. Acesso em: 8 mar. 2019.

CRESCIMENTO econômico. Prefeitura de Macaé, 2013. Disponível em: http://www.macae rj.gov.br/conteudo/leitura/titulo/crescimento-economico. Acesso em: 17 fev. 2019.

FONTES, Marianna. Pré-projeto mostra como deve ficar a Ponte da Barra. O Debate, Macaé 27 mar. 2015. Disponível em: https://www.odebateon.com.br/site/noticia/detalhe/33278/ pre-projeto-mostra-como-deve-ficar-a-ponte-da-barra. Acesso em: 8 mar. 2019.

FUNDAÇ̃̃O OSCAR NIEMEYER. Obra/Arquitetura: Prefeitura de Macaé. 1985. Disponível em: http://www.niemeyer.org.br/obra/pro270. Acesso em: 17 mar. 2019.

GIESBRECHT, Ralph Mennucci. Estações ferroviárias do Brasil: Macaé. 2018. Disponível em: http://www.estacoesferroviarias.com.br/efl_rj_litoral/macae.htm. Acesso em: 8 mar. 2019.

IBGE. [Dados do Censo demográfico de 2010]. Disponível em: http://www.ibge.gov.br. Acesso em: 5 mar. 2019.

LISBOA, Andréa. Inaugurado Mercado do Peixe: alto padrão e identidade. Prefeitura de Macaé, 29 jun. 2015. Disponível em: http://www.macae.rj.gov.br/noticias/leitura/noticia/inau gurado-mercado-do-peixe-alto-padrao-e-identidade\#prettyPhoto. Acesso em: 8 mar. 2019

MACAÉ. Lei complementar $n^{\circ} 141$, de 3 de março de 2010. Dispõe sobre o Código de Urbanismo do Município de Macaé e dá outras providências. Diário Costa do Sol, Macaé, 6 mar. 2010

MACAÉ TIPS. Trilha: Cachoeira da Fortuna. 2017. Disponível em: http://macaetips.com/ event/trilha-cachoeira-da-fortuna-nivel-facil/. Acesso em: 15 fev. 2019.

MACEDO, Silvio Soares et al. Os sistemas de espaços livres e a constituição da esfera pública contemporânea no Brasil. São Paulo: Edusp, 2016.

MAGNOLI, Miranda. Em busca de outros espaços livres. Paisagem e Ambiente, São Paulo, n. 21, p. 141-174, 2006. DOI: https://doi.org/10.11606/issn.2359-5361.v0i21p141-173

PINHOL, Alex. Mapas do Brasil preto e branco. Minuto Ligado, [S. I.], 18 nov. 2012. Disponível em: https://minutoligado.com.br/mapas/mapa-do-brasil-para-colorir/attachment/ mapa-do-brasil-preto-e-branco/ Acesso em: 3 out. 2019.

SILVA, Jonathas Magalhães Pereira da. As unidades de paisagem como método de análise da forma urbana: reflexões sobre sua incorporação pelo campo disciplinar da arquitetura e urbanismo. Cadernos do Proarq Rio de Janeiro, Rio de Janeiro, v. 20, p.71-93, 2013.

SIQUEIRA, Márcio. História de Macaé contada através de uma praça. O Debate, Macaé 15 nov. 2008. Disponível em: https://odebateon.com.br/site/noticia/detalhe/5540/historiade-macae-contada-atraves-de-uma-praca. Acesso em: 8 mar. 2019.

SIQUEIRA, Márcio. Macaé imortaliza traços de Niemeyer. O Debate, Macaé, 26 jul. 2017 Disponível em: https://odebateon.com.br/site/noticia/detalhe/39463/macae-imortaliza-tracos-de-niemeyer. Acesso em: 8 mar. 2019.
Fernanda de Abreu Pereira

Instituto Federal de Educação, Ciência e Tecnologia Fluminense (IFF Campos Centro)

Rua Dr. Siqueira, 273, Campos dos Goytacazes, Rio de Janeiro, Brasil, CEP 28030-130

Orcid: https://orcid.org/0000-0002-3930-6977

E-mail: abreufernanda93@gmail.com

Danielly Cozer Aliprandi

Instituto Federal de Educação, Ciência e Tecnologia Fluminense (IFF Campos Centro).

Rua Dr. Siqueira, 273, Campos dos Goytacazes, Rio de Janeiro, Brasil, CEP 28030-130

Orcid: https://orcid.org/0000-0002-0727-8481

E-mail: danielly.aliprandi@iff.edu.br
Nota do Editor

Submetido em: 25/03/2019 Aprovado em: 21/09/2019 Revisão do texto: Tikinet 